\title{
The Role of Leadership and Training in Improving Operational Leadership Competences
}

\author{
Heni Mardiningsih \\ Department of Education Management \\ Universitas Negeri Surabaya \\ Surabaya, Indonesia \\ Heni.18005@mhs.unesa.ac.id
}

\begin{abstract}
The purpose of this study was to find out and analyze the role of Level IV Leadership Education and Training in improving operational leadership competencies in the ministry of religion in East Java. This study uses a qualitative descriptive approach that describes the data obtained through interviews, observation and documentation. The role of Level IV Leadership Education and Training can be maximized in the formation of operational leadership competencies if participants are present in accordance with specified requirements, there is intensive and ongoing coordination between the organizer and the leader who is the participant, mentor and mentor taking time in guiding participants in project implementation changes, the resource person has a teaching competency certificate, participants are more focused on implementing change projects in their institution, involving resource persons in evaluating participant evaluations at the end of the activity, and evaluating and monitoring change projects in the short, medium and long term.
\end{abstract}

Keywords-role; level IV leadership education and training; operational leadership competencies

\section{INTRODUCTION}

In entering the dynamic era of globalization and in order to welcome the ASEAN economic community, the Indonesian government is required to be able to develop themselves and increase competitiveness with other countries, especially in terms of improving the quality of public services. Globalization creates and includes markets and competition between institutions and between nations [1]. Global competition, performance funding, and transparency change institutions and countries better prepared to face global challenges, the opinions of previous researchers [2]. For this reason, the Indonesian government must prepare everything to compete with the MEA (Asian Economic

Community countries. One important factor in increasing national competitiveness and development is the quality of developing the competencies of government agency officials through leadership education and training. Echelon IV leaders play a role in planning agency activities and leading the implementation of activities. In Government Regulation No. 101 of 2000 concerning Education and Training of Civil Servants, it was stipulated that Civil Servants who have or will sit in echelon IV structural positions are required to attend Level IV Leadership Education and Training in order to have operational leadership competencies [3] Competence can be defined as having skills, knowledge, qualifications, or capacities needed, competency refers to various abilities in various domains or aspects of performance, competency is a person's internal characteristics and actions that can be observed from someone [4]. Characteristics of leaders do not perform well because they do not have the required leadership competencies, this causes poor performance and results in the organization failing to achieve its objectives [5]. Implementation of Level IV Leadership Education and Training in Surabaya Religious Education and Training was attended by 35 participants consisting from Regency / City echelon IV officials in East Java. Leadership education and training is carried out by organizations to improve official leadership competencies in holding organizational positions [6]. Based on preliminary observations, the researchers saw that there was distrust from some participants, leaders and communities who said that the implementation of education and training was only for administrative needs. The initial data was obtained by researchers from the implementation of classroom learning with the appearance of several opinions from participants that the leadership education and training that was followed was only a prerequisite for echelon IV officials who had occupied echelon IV positions. Likewise, the opinion of some echelon III leaders as direct superiors of participants, who were interviewed during the coordination meeting, said that Leadership Education and Training is only an administrative requirement that must be followed by echelon IV officials, so that some echelon IV officials are reluctant to participate in Leadership Education and Training very long, this data was confirmed by the opinions of leadership education and training providers when inviting participants, while some participants chose to resign for various reasons.

Based on the description presented above with various phenomena of the attitude and quality of echelon IV officials in the Ministry of Religion of East Java Province, researchers are interested in analyzing and assessing the extent of the role of Level IV Leadership education and training in improving operational leadership competencies. Role theory states how a person behaves in carrying out a role [7]. 
Based on the background presented above, the problem is formulated as follows: What is the role of Level IV leadership education and training in improving operational leadership competencies? To find out and analyze the role of level IV leadership education and training in improving operational leadership competencies within the Ministry of Religion's Office of East Java Province.

\section{METHOD}

This study using a qualitative descriptive approach. We will describe the role of Level IV Leadership Education and Training in improving operational leadership competencies in the Religious Education and Training Center in Surabaya, East Java.

Qualitative research methods are defined as research methods that are based on post positivism, which is a study that is based on natural object conditions where the researcher is a key instrument. The sampling of data sources in this study is purposive sampling, the technique of collecting data by means of triangulation, analysis of inductive / qualitative data and the results of more qualitative research emphasizes the meaning of the generalization.

Researchers as key informants will conduct interviews with alumni of education and training participants, leaders, organizers and the community by asking a number of questions in accordance with interview guidelines. The data obtained from the interview results, it will be collected both in the form of text and the results of recordings when conducting interviews with participants. Data in the form of words or text are then analyzed. The results of the analysis can be in the form of descriptions in the form of themes which interpretations will be made by researchers to capture the deepest meanings [8].

The location of this study was conducted at the Surabaya Religious Education and Training Center in East Java Province, from July 2018 to April 2019.

Determination of informants in this study based on the capacity of the variables in the study, namely Level IV Leadership Education and Training and operational leadership competencies in the Education and Training Center of the Ministry of Religion, East Java are:

a. Head of Regency / City Ministry of Religion Office in East Java Province.

b. Organizers and managers of Level IV Leadership Education and Training.

c. Alumni of the 23rd Level IV Training and Leadership Training.

d. Staff / subordinates of the 23rd Grade IV Leadership and Education Training participants

e. Education and Training Organizers.

Interviews were carried out by researchers using interview guidelines conducted for several Heads of Ministry of Religion Offices in East Java Province who were attending coordination meetings, Grade IV alumni of Education and Training of Class 23 conducted interviews face-to-face and through communication media, managers and organizers of education and interview training conducted face-to-face, the selection of participants in this study was based on purposive sampling, which was considered by researchers to be able to provide accurate information. The aspects of the question include: The Role of Level IV Leadership and Education Training, competency measurement in each stage of education and training activities and operational leadership competencies.

Observation activities carried out by researchers to obtain more accurate data information about the things studied and to determine the relevance of the answers to the informants with the reality that occurred in the field. Observations in this study were observations made by researchers when monitoring and evaluating Level IV Leadership Education and Training in several alumni originating agencies. This is to see whether the change project can run in the short, medium and long term.

The researcher analyzes internal documents from the training alumni to analyze GPP (the idea of a change project) reports, RPP (project design changes) Reports, LPP (change project report) Reports, mentoring forms by mentors and coaches as well as value perceptions delivered by examiners, mentors and coaches. Whole external documents can be obtained from researchers from various sources of searching on google, television media and reports on changes in project participants from the Supreme Court.

In this study the technique used to analyze the data is a qualitative approach which has the main purpose of collecting descriptive data in order to describe the object of research in detail and in depth to develop concepts or understanding of a social phenomenon. This type of qualitative research does not have a specific design but a research design that develops in accordance with the atmosphere and conditions at the time the research was conducted. The steps for analyzing data according to Miles and Huberman (2007) are:

\section{a. Data reduction}

In this study researchers reduced and sorted data from observations, interviews, and documentation. Because the data obtained from the field is still complex and raw. So the researcher will only select data that is truly relevant with regard to the role of Education and Level IV Leadership Training and operational leadership competencies.

\section{b. Display Data}

Data is presented in the form of narrative texts to explain the role of Level IV Leadership Education and Training and then correlate with operational leadership competencies that are built in each stage of activities in education and training at the Surabaya Education and Training Center in East Java Province.Then that data if it is based on the theory - the theory that have been raised previously to obtain a clear picture. The entire data that has been processed by the researcher will then be collected into one by the researcher and then presented to reach the conclusion stage.

c. Verification and Conclusion 
Conclusion is directed to general things to find out the answer to the problem. The problem of this study relates to Level IV Leadership Education and Training, its role in improving operational leadership competencies for echelon IV officials in the Ministry of Religion of East Java Province.

\section{RESULTS AND DISCUSSION}

The results of this study describe the data obtained through interviews, observation and documentation. In conducting data analysis, researchers used the Level IV Roles of Education and Training for participants and institutions of participants, operational leadership competency measurements of participants from the learning agenda stages in education and training, participant evaluations based on standards for innovation planning and change management, process training, competency instructor, coach competency and mentor competency as direct supervisor. The curriculum of various institutions emphasizes a variety of leadership skills and competencies and teaches leadership competencies to demonstrate personal quality [9]. Leadership curriculum focuses on various competencies, harmonizing leadership curricula with competency models, will create opportunities to standardize outcome evaluation, which leads to better measurement of student competencies and a better understanding of best practices [9]. / The city is indeed consistent with the goals and objectives of Leadership Education and Training contained in LAN Regulation Number 20 of 2015 concerning Implementation Guidelines for Level IV Leadership Education and Training which are operational leadership competencies namely the ability to plan agency activities and lead the successful implementation of these activities [10], consisting of:

1. Building the character and attitude of integrity behavior in accordance with the legislation and the ability to uphold public ethics, adhere to values, norms, morality and be responsible for leading the work unit;

2. Make plans for implementing agency activities;

3. Collaborating internally and externally in managing organizational tasks towards the effectiveness and efficiency of the activities of the institution;

4. Making innovations in accordance with the field of duty in order to realize the implementation of more effective and efficient activities;

5. Optimizing all potential internal and external resources of the organization in implementing institutional unit policy strategies.

Training in four different qualification levels with different functions, tasks and responsibilities, for the achievement of skills from the experience gained in performing the best functions obtained at each level [11].

The curriculum in the training that produces competencies will be obtained through several stages, when the first stage can be passed and the competency is measured, the student progress to the next training stage [4].
To achieve operational leadership competencies, it can be analyzed according to the structure of the Level IV Leadership Training curriculum which consists of five learning stages, namely:

\section{Stage of Diagnosing Change in Needs}

This stage is the stage of determining the field of management of organizational activities that will undergo changes. At this stage, participants are equipped with the ability to diagnose organizations so that they can identify areas of organizational activity that need to be reformed.

The researcher analyzed the document from the report about the ideas of the change project made by the participants, interviewed the participants and organizers. Competencies built at this stage are the ability of participants to identify problems that exist in their institutions between current conditions and expected conditions for better public services. And pouring out the idea of a change project (GPP), the researcher will analyze how far the competencies possessed by the participants in compiling the GPP are in accordance with the criteria set in the GPP preparation and to measure how much participants receive material in stage I. Participants experience obstacles in determining issues priority / priority issues that will be used as ideas for change projects, due to budget constraints used to make changes and lack of management support. So, there is doubt in determining the core problem that will be solved. Although the identification of problems has been identified using an analysis tool, the end result is in the decisions of the leadership and management of the organization.

\section{Taking Ownership Stage (Breakthrough 1)}

This learning phase directs participants to build organizational learning or awareness and the importance of making innovative changes in the area of problematic organizational activities. Issues that exist within the organization must be communicated by the participants together with stakeholders and obtain leadership approval.

At this stage the researcher analyzes several reports to find out the competencies built by the participants, such as the ability of participants to convey the idea of a change project to their immediate supervisor (mentor) and coworkers and staff. This is to equalize perceptions about the area of change that will be carried out in the organization. At this stage, participants must collect complete data as evidence of activities carried out in their institution for 7 days. Participants also fill out guidance forms by mentors and mentors.

\section{Stage of Designing Changes and Building Teams}

This learning phase equips participants with the knowledge of making comprehensive changes to the ideal conditions of management of expected organizational activities. In addition, participants are also equipped with the ability to identify stakeholders related to their design changes, including effective team building techniques to realize these changes. Good team work will create good job satisfaction and organizational commitment [9]. This stage ends with the presentation of the Change Project Design (RPP) in front of examiners, mentors and coaches in RPP seminars. Participants will get input, suggestions, criticisms 
and support for the project design changes that have been presented for the perfection of the design.

The analysis carried out by researchers from the report on the project changes to determine the competencies of participants in designing a change project which consists of determining the title of the change project, the purpose and benefits of the change project, the scope of activities in the change project, and analyzing the stakeholders as effective teams as well as the ability of participants to submit a change project design in a change project design seminar. The examiner will assess the RPP from the planning of innovations made by the participants, which consist of the types of innovations in the change project, the benefits of the change project for stakeholders, the clarity of the stages of activities in the change project and supporting and resistant stakeholders. In this stage, some participants have not been able to determine the right title in accordance with the contents of the change project, formulate the goals and benefits of short-term, mid-term and long-term changes, scope of change, identification of stakeholders, effective team formation and estimate changes in project budgets.

\section{Laboratory Leadership Stage (Breakthrough II)}

This learning phase directs participants to apply and test their leadership capacity. Participants return to their workplace and lead the implementation of the Change Project that has been designed. The researcher analyzes the coaching forms by the coach or mentor as well as some physical evidence used as an attachment in the report. Competencies built in this stage are the ability of participants to implement RPP in their respective institutions, leading direct activities - activities to achieve the goals set out in the RPP.

There are several gaps found by researchers, namely the lack of care for some mentors and coaches in conducting guidance. After in-depth interviews with participants, mentors and coaches, the participants were less intensive in guiding both the mentor and the coach, participants were busy doing their routine work, so the implementation of the change project was carried out when there was no work in the institution.

\section{Evaluation Phase}

The learning evaluation phase is the stage of sharing knowledge and experience in leading the implementation of the Change Project delivered at the leadership laboratory seminar. Only participants who have successfully implemented the Change Project have been declared to have operational leadership competencies and have passed the Level IV Leadership Education and Training. Whereas those who were unsuccessful were given certificates following Level IV Leadership Education and Training.

Based on the observations of the researchers that the organizers of education and training never involved resource persons in recapitulating the participants' scores at the end of the training. The organizer only inputs the participant's value into the simdiklat application and prints the final score. The resource person will choose and combine several assessments while accompanying the participants and determine whether and when competence is achieved, so that there are high-risk decisions regarding competency so that participants are declared to pass [4].

\section{CONCLUSION}

Based on the research that has been described above, then the research titled "The Role Leadership Education and Training Level IV in enhancing leadership competencies operations ", will contribute to improved quality of care and improving the competence of echelon IV if the remaining gaps in the implementation of education and training can finding the best solution or solution, so that the role of education and training can be maximized in shaping operational leadership for echelon IV structural officials. As for the conclusions of the researchers are as follows:

1. The existence of intensive and continuous coordination between the organizers of Leadership Education and Training with leaders who become direct supervisors of participants;

2. There is support from the direct leader / supervisor of the participants delivered through a letter of support for the idea of a change project or discussion in a change project design seminar. With the support of the leadership of the project changes, the participants will be motivated to carry out activities that have been established in the milestone;

3. Mentors and coaches must provide time to mentally train participants, especially guarding participants when taking ownership/breakthrough 1 . So that there are appropriate directions when the participants go beyond this stage of 2 (two);

4. The resource person must have competence in Level IV Leadership Education and Training as evidenced by a competency certificate issued by the Le State Administration (LAN);

5. The resource person must develop innovative learning in delivering some training material. (always connecting training materials with change projects) using simulation learning methods, practices and role play to sharpen understanding of training participants;

6. The leader as the direct supervisor of the participant gives the participants free time to complete the change project, and can delegate organizational activities to the participants' co-workers. So that participants focus more on implementing change project activities more optimally;

7. In the participant evaluation phase at the end of the training, the organizers of education and training should coordinate with the resource persons to match the results of the scores recapitulated by the committee as providers of education and training. Likewise, the determination of the qualifications of participants who get the title is very satisfying, very good, good and sufficient, and determine the best participants in education and training. This is done to avoid gratification by participants.

Based on the conclusions above, the researcher put forward some suggestions or recommendations as follows: 
1. Participants in leadership education and training sent must comply with the requirements set out in the Decree of the Head of State Administration Agency Number 1 of 2014 concerning Selection Guidelines for candidates for Level IV Leadership Education and Training.

2. Mentor support as the direct supervisor of the participant in the form of a letter of support for the change project idea that has been signed must be agreed upon until the change project is implemented in the short, medium and long term.

3. Guidance forms for mentors and coaches must be filled in accordance with the date of guidance carried out by participants with attached physical evidence.

4. The resource person must take part in the Training of Trainer Education and New Pattern Leadership Training and be declared to pass with a competency certificate as a teacher issued by the LAN.

5. Preparation for the implementation of Level IV Leadership Education and Training must be carried out by holding preparatory meetings between the organizers and resource persons.

6. The resource person must disseminate some of the material available at Level IV Leadership Education and Training so that there is renewal and development of both the learning method, the willingness of props, module development and systematics in the preparation of GPP, RPP and LPP.

7. Involve resource persons in evaluating the final evaluation of Level IV Leadership and Education Training.

8. Availability of budgets to monitor and evaluate change projects in the short, medium and long term.

\section{REFERENCES}

[1] Samier, EA (2015). Globalisasi pendidikan tinggi sebagai masalah keamanan sosial dan budaya. Futures Kebijakan dalam Pendidikan, 13(5),683-702. https://doi.org/10.1177/1478210315579558

[2] Lane, JE (2015). Internasionalisasi pendidikan tinggi: Mengapa pemerintah peduli. Dalam E. Ullberg (Ed.), Perspektif baru tentang internasionalisasi dan daya saing (hal. 17-30). Dordrecht, Belanda: Springer. https://doi.org/10.1007/978-3-319-11979-3_3

[3] Government Regulation Number 101 of 2000 concerning Civil Servants Education and Training.

[4] Amy B. Fraser, MD, Emma J. Stodel, PhD, Alan J. Chaput, PharmD, $\mathrm{MD}$, "Curriculum reform for residency training: competence, change, and opportunities for leadership "Can J Anesth Vol 63 No.875-884, 4 April 2016, Canadian Anesthesiologists' Society,2016

[5] Maduka, Nnamdi, Edwards, Helen, Greenwood, David, Osborne, Allan and Babatunde, Solomon, "Analysis of competencies for effective virtual team leadership in building successful organizations" Vol.25 No.696-712, Emerald, 2018.

[6] Irfan Ibrahim, "The Effect of New Pattern of Level IV Leadership Training and Education Policy Implementation on Leadership Competence of Supervisory officials in Gorontalo Provincial Government", Vol.8 No.2 December 2018.

[7] Cohen Bruce J, 2009, "Peranan, sosiologi suatu pengantar, Rineka Cipta, Jakarta.

[8] Sugiyono. (2009) Metode Penelitian Kuantitatif dan Kualitatif. Bandung:Alfabeta.

[9] Allison MB Webb, MAT, Nicholas E. Tsipis, MPH, Taylor R. McClellan Michael J. McNeil, Meng Meng Xu, Joseph P. Doty, PhD, dan Dean C. Taylor, MD, "A First Step Toward Understanding Best Practices in Leadership Training in Undergraduate Medical Education: A Systematic Review", Academic Medicine, Vol.89, No.11:1563-1570, November2014.

[10] Regulation of the Head of the State Administration Agency Number 20 of 2015 concerning Guidelines for Implementing Level IV Leadership and Education Training.

[11] Francesda D'elia, Filomena Mazzeo, Gaetano Raiola, "The core curriculum in the university training of the teacher of physical education in Italy",Vol.13 No.25:1988-5202, 2018. 